\title{
Correction to: The proteorhodopsins of the dinoflagellate Oxyrrhis marina: ultrastructure and localization by immunofluorescence light microscopy and immunoelectron microscopy
}

\author{
Erhard Rhiel $^{1,2} \cdot$ Martin Westermann $^{3} \cdot$ Frank Steiniger $^{3} \cdot$ Christian Hoischen $^{4}$
}

Published online: 23 July 2021

(c) The Author(s) 2021

\section{Correction to: Protoplasma (2020) 257:1531-1541 https://doi.org/10.1007/s00709-020-01530-z}

The article The proteorhodopsins of the dinoflagellate Oxyrrhis marina: ultrastructure and localization by immunofluorescence light microscopy and immunoelectron microscopy written by Erhard Rhiel, Martin Westermann, Frank Steiniger and Christian Hoischen, was originally published electronically on the publisher's internet portal on 3 July 2020 without open access. With the author(s)' decision to opt for Open Choice the copyright of the article changed on 5 July 2021 to (C) The Author(s) 2021 and the article is forthwith distributed under a Creative Commons Attribution 4.0 International License, which permits use, sharing, adaptation, distribution and reproduction in any medium or format, as long as you give appropriate credit to the original author(s) and the source, provide a link to the Creative Commons licence, and indicate if changes were made. The images or other third party material in this article are included in the article's Creative Commons licence, unless indicated otherwise in a credit line to the material. If

The original article can be found online at https://doi.org/10.1007/ s00709-020-01530-z.

Erhard Rhiel

erhard.rhiel@uni-oldenburg.de

1 Planktology, Institute for Chemistry and Biology of the Marine Environment, Carl von Ossietzky University Oldenburg, Carl-von-Ossietzky-Straße 9-11, 26111 Oldenburg, Germany

2 Planktology, ICBM, Carl von Ossietzky University Oldenburg, P. O. B. 2503, 26129 Oldenburg, Germany

3 Electron Microscopy Center at the Jena University Hospital, Friedrich-Schiller-University Jena, Ziegelmühlenweg 1, 07743 Jena, Germany

4 CF Imaging, Leipniz Institute On Aging, Fritz-Lipmann-Institute (FLI), Beutenbergstraße 11, 07745 Jena, Germany material is not included in the article's Creative Commons licence and your intended use is not permitted by statutory regulation or exceeds the permitted use, you will need to obtain permission directly from the copyright holder. To view a copy of this licence, visit http://creativecommons. org/licenses/by/4.0.

The Original article has been corrected.

Publisher's note Springer Nature remains neutral with regard to jurisdictional claims in published maps and institutional affiliations. 